\title{
Effect of thermal treatments on technological properties of wood from two Eucalyptus species
}

\author{
PEDRO HENRIQUE G. DE CADEMARTORI ${ }^{1}$, ANDRÉ L. MISSIO ${ }^{2}$, \\ BRUNO D. MATTOS ${ }^{3}$ and DARCI A. GATTO ${ }^{2,4}$ \\ ${ }^{1}$ Centro de Ciências Florestais e da Madeira/PPGEF, Universidade Federal do Paraná, \\ Lothário Meissner 900, 80210-170 Curitiba, PR, Brasil \\ ${ }^{2}$ Engenharia Florestal/PPGEF, Laboratório de Produtos Florestais, Centro de Ciências \\ Rurais, Universidade Federal de Santa Maria, Caixa Postal 221, 97105-900 Santa Maria, RS, Brasil \\ ${ }^{3}$ Programa de Pós-Graduação em Engenharia e Ciência dos Materiais/PIPE, \\ Universidade Federal do Paraná, Centro Politécnico, 81521-990 Curitiba, PR, Brasil \\ ${ }^{4}$ Engenharia de Materiais/PPGCEM, Universidade Federal de Pelotas, Félix da Cunha 809, 96010-000 Pelotas, RS, Brasil \\ Manuscript received on March 27, 2013; accepted for publication on April 7, 2014
}

\begin{abstract}
The effect of thermal treatments on physical and mechanical properties of rose gum and Sydney blue gum wood was evaluated. Wood samples were thermally modified in a combination: pre-treatment in an autoclave $\left(127^{\circ} \mathrm{C}-1 \mathrm{~h}\right)$ and treatment in an oven $\left(180-240^{\circ} \mathrm{C}-4 \mathrm{~h}\right)$; and only treatment in an oven at $180-240^{\circ} \mathrm{C}$ for 4h. Chemical changes in the structure of woods were evaluated through infrared spectroscopy. Evaluation of physical properties was performed through mass loss, specific gravity, equilibrium moisture content and dimensional stability tests. Surface changes were analyzed through apparent contact angle technique and static bending tests were carried out to evaluate the mechanical behavior. Use of pre-treatment in autoclave affected the properties analyzed, however oven, resulted in the highest changes on wood from both species. Chemical changes were related to the degradation of hemicelluloses. Moreover, a significant decrease of hygroscopicity and mechanical strength of thermally modified woods was observed, while specific gravity did not significantly change for either of the species studied. The best results of decrease of wettability were found in low temperatures, while dimensional stability increased as a function of temperature of exposure in oven. The highest loss of mechanical strength was observed at $240^{\circ} \mathrm{C}$ for both species.
\end{abstract}

Key words: hygroscopicity, chemical changes, wettability, heat treatment, mechanical strength.

\section{INTRODUCTION}

Over the years, many processes have been developed in order to protect wood against xylophages agents, mainly treatments of impregnation with chemical products. Environmentally friendly and efficient alternatives towards changes of technological properties of wood were also developed, such as

Correspondence to: Pedro Henrique G. de Cademartori

E-mail: pedrocademartori@gmail.com thermal treatments. According to Syrjanen (2001), thermal treatment is an ecological alternative to modify wood and can be used to produce many products like doors, windows, kitchen furniture, garden furniture and floors.

Thermal treatment occurs between 180 and $260^{\circ} \mathrm{C}$ due to temperatures lower than $140^{\circ} \mathrm{C}$ do not significantly affect the structure of material, and temperatures higher than $260^{\circ} \mathrm{C}$ result in 
undesirable degradation (Hill 2006). According to Mitchell (1988), and Korkut and Guller (2008), the temperature is the parameter of process responsible for the highest effect of modification in the properties of thermally treated wood.

Many methods of thermal treatments were developed in different countries, mainly on the European continent, such as Finnish Thermo Wood (Finland), French Rectification and Bois Perdure (France), Oil Heat Treatment (Germany) and Dutch Plato Wood (Holland) (Militz 2002).

On the one hand, thermal treatment promotes changes in the physical properties of wood, especially as swelling and shrinkage, equilibrium moisture content, weathering resistance, color and mass loss. In this context, physical changes of thermally modified woods are highly dependent on the conditions of treatments (Hill 2006, Korkut et al. 2008). At the same time, thermal treatments modifying the wood's wettability, which is directly related to the chemical changes on wood structure, especially to the degradation of the hemicelluloses.

On the other hand, thermal treatments can change mechanical properties and, consequently, according to Borrega and Kärenlampi (2008), can limit the structural use of wood pieces jointly with mass loss. Moreover, breaking of hemicelluloses and cellulose chains can significantly reduce wood strength (Poncsák et al. 2006). According to Fengel and Wegener (2003), the components of thermally modified wood are stable up to $100^{\circ} \mathrm{C}$. However, polysaccharides content decreases when exposed to high temperatures (above $100^{\circ} \mathrm{C}$ ) due to its more sensitive reactivity in comparison to cellulose.

Wood from rose gum is rated as strength class S3 and SD4 and wood from Sydney blue gum is rated as class S3 and SD4 (AUSTRALIAN/NEW ZEALAND STANDARD 2000). Therefore, thermal treatments could be a great alternative to improve physical and aesthetic properties, increasing market value and, consequently, the number of applications of wood from rose gum or Sydney blue gum.
Considering these facts, the present study aimed to evaluate physical, surface and mechanical properties of rose gum (Eucalyptus grandis Hill ex. Maiden) and Sydney blue gum (Eucalyptus saligna $\mathrm{Sm}$ ) woods thermally modified under different conditions.

\section{MATERIALS AND METHODS}

\section{RAW MATERIAL}

Six rose gum (Eucalyptus grandis Hill ex. Maiden) and six Sydney blue gum (Eucalyptus saligna $\mathrm{Sm}$ ) trees were randomly selected from experimental fast-growing population located in the north coast of the state of Rio Grande do Sul, southern Brazil (30¹4'09.73”S, 50¹9'55.07'W). Rose gum trees were 17 years old, average diameter at breast height $(\mathrm{DBH}, 1.30 \mathrm{~m})$ of $37.1 \mathrm{~cm}$ and total height of $35.7 \mathrm{~m}$; Sydney blue gum trees were 17 years old, average diameter at breast height (DBH, $1.30 \mathrm{~m}$ ) of $29.5 \mathrm{~cm}$ and total height of $30 \mathrm{~m}$.

Two hundred and seventy samples (15 samples per treatment for each specie) measuring 16 x 16 x 250 $\mathrm{mm}$ (radial $\mathrm{x}$ tangential $\mathrm{x}$ longitudinal) were cut from the first $\log$ ( $3.15 \mathrm{~m}$ length) of each tree. The samples were prepared only with straight grain, heartwood and absence of warps. All the samples were conditioned in a climatic chamber $\left(20^{\circ} \mathrm{C}\right.$ and $65 \%$ of relative humidity) to stabilize the equilibrium moisture at $12 \%$, which was the initial point for the thermal treatments.

\section{THERMAL TREATMENTS}

Table I shows the eight distinct thermal treatments applied in rose gum and Sydney blue gum woods. Treatment 1 (control) was kept in a climatic chamber $\left(20^{\circ} \mathrm{C}\right.$ and $65 \%$ of relative humidity) the whole time.

One hundred and twenty wood samples were modified through combined treatments in an autoclave sterilizer and in an oven. To achieve this, a pre-treatment (wet conditions and indirect steam) in an autoclave at $127^{\circ} \mathrm{C}$ and $1.5 \mathrm{kgf.cm}{ }^{-2}$ for 1 hour was carried out. Pre-treated samples were conditioned in a climatic chamber to stabilize the equilibrium moisture. Then, these samples 
TABLE I

Thermal treatments performed in rose gum and Sydney blue gum woods.

\begin{tabular}{ccc}
\hline Treatment & Temperature $\left({ }^{\circ} \mathbf{C}\right)$ & Time $(\mathbf{h})$ \\
\hline 1 & 20 & - \\
2 & 180 & 4 \\
3 & $127+180$ & $1+4$ \\
4 & 200 & 4 \\
5 & $127+200$ & $1+4$ \\
6 & 220 & 4 \\
7 & $127+220$ & $1+4$ \\
8 & 240 & 4 \\
9 & $127+240$ & $1+4$ \\
\hline
\end{tabular}

were treated in an oven (heating rate: $2^{\circ} \mathrm{C} \cdot \mathrm{min}^{-1}$ ) without forced air circulation at 180, 200, 220 and $240^{\circ} \mathrm{C}$ for 4 hours (dry conditions) after reaching the temperature of treatment.

Another one hundred and twenty wood samples were treated only in an oven with heating rate of $2^{\circ} \mathrm{C} \cdot \mathrm{min}^{-1}$ and without forced air circulation at $180,200,220$ and $240^{\circ} \mathrm{C}$ for 4 hours after reaching the temperature of treatment. All the treated samples were kept in a climatic chamber $\left(20^{\circ} \mathrm{C}\right.$ and $65 \%$ of relative humidity) until they reached the equilibrium moisture content to perform the tests.

\section{INFRARED SPECTROSCOPY}

The chemical modifications were measured through attenuated total reflectance infrared spectroscopy (ATR-IR) using an equipment by direct transmittance at a resolution of $4 \mathrm{~cm}^{-1}$ for 32 scans in the range from 700 to $4000 \mathrm{~cm}^{-1}$. The main evaluations occurs in the range $1800-700 \mathrm{~cm}^{-1}$, which is known as fingerprint of wood (Pandey 1999). All the spectra were generated through an average of six spectra for each treatment.

\section{MASS Loss, EQUILIBRIUM MoISTURE CONTENT AND}

\section{SPECIFIC GRAVITY}

Mass loss (WL) was measured through the difference of weight of the samples before and after the thermal treatments (Cademartori et al. 2012).
Equilibrium moisture content (EMC) was measured using American Society for Testing and Materials D143-94 standard (ASTM 2000). Likewise, specific gravity $\left(\rho_{\mathrm{b}}\right)$ was measured by ratio of dry weight and wet volume.

DIMENSIONAL STABILITY AND WETTABILITY

Dimensional stability was evaluated through volumetric $(\Delta \mathrm{V})$ and linear $(\Delta \mathrm{l}$ in radial and tangential direction) swelling. To achieve this, the samples (in equilibrium) measuring $16 \mathrm{~mm}$ x $16 \mathrm{~mm}$ x $50 \mathrm{~mm}$ (radial $\mathrm{x}$ tangential $\mathrm{x}$ longitudinal) were immersed in distilled water until the fibers' saturation. After the immersion, weight and size (length, width and thickness) of the samples were measured.

Then, the samples were dried in an electrical oven at $103 \pm 2^{\circ} \mathrm{C}$ until they reached constant weight. The physical properties of volumetric $(\Delta \mathrm{V})$ and linear $(\Delta \mathrm{l})$ swelling were measured as described by Cademartori et al. (2012).

Wettability was studied through the apparent contact angle technique using a goniometer (sessile drop method) as described by Cademartori et al. (2013). Measurement of the apparent contact angle were performed through the deposition of a distilled water droplet $(5 \mu l)$ in three distinct surface points of both radial and tangential direction of each of five samples $(16 \mathrm{~mm} \times 16 \mathrm{~mm} \times 250 \mathrm{~mm})$ per treatment. The apparent contact angle was measured in seven distinct times with 15 seconds intervals up to a total of 90 seconds. The first measurements was after 5 seconds of the droplet contact on the wood surface.

\section{MEChANICAL Properties}

Mechanical properties (modulus of elasticity and modulus of rupture) of thermally modified wood samples $(16 \mathrm{~mm} \times 16 \mathrm{~mm} \times 250 \mathrm{~mm})$ were measured by static bending tests in a universal machine with capacity of $300 \mathrm{kN}$. The tests were performed using a three-point bending apparatus according to American Society for Testing and Materials D14394 standard (ASTM 2000). 
STATISTICAL ANALYSIS

The collected data were analyzed by descriptive statistic and factorial analysis of variance with additional treatment in a factorial arrangement $2 \times 4+1$, i.e., use of steam pre-treatment in autoclave, temperature of treatment and control treatment, respectively. Due to the absence of a control treatment, mass loss (WL) was analyzed by analysis of variance in a factorial arrangement $2 \mathrm{x}$ 4. For the analysis of variance, an induced $p$-value by $\mathrm{F}$ statistics at $5 \%$ and $1 \%$ of probability of error was used. When the null hypothesis $(p<0.05)$ was rejected, the mean values were compared with Tukey Test at $5 \%$ of probability of error.

\section{RESULTS AND DISCUSSION}

INFRARED SPECTROSCOPY (ATR-IR)

As observed in Fig. 1, the changes in peaks were only similar for the treatment in oven and in a combination of oven and autoclave. When compared to treatment 1 (control), thermal treatments significantly changed the chemical structure of rose gum and Sydney blue gum wood.

The high changes as a function of temperature of treatment were found in the peaks related to the hemicelluloses, mainly at $1731 \mathrm{~cm}^{-1}$, which is typical in unconjugated ketone and carboxyl acids present in lignin and hemicelluloses (Colom et al. 2003). After treatment 8 and 9, the intensity of this peak was very small due to the action of the thermal treatment on the chemical structure of wood. According to Fengel and Wegener (2003), when wood is exposed to high temperatures, the polysaccharides content significantly decrease because have more sensible reactivity than the cellulose. The peak at $1105 \mathrm{~cm}^{-1}$ (OH association in hemicelluloses and cellulose) increases with increasing temperature of treatment for both species, which was also found by Ding et al. (2011) in a study with thermally modified Mongolian pine wood.

At 1592,1504 and $1460 \mathrm{~cm}^{-1}$, peaks representative of lignin showed a stabilization or slight increase as a function of the temperature of treatment. This is related to the degradation of the polysaccharides and, consequently, the increase of proportion of lignin in the structure of thermally modified woods.

\section{PhySICAL PROPERTIES}

Statistical analysis of physical properties (Table II) showed that most of the parameters evaluated were significantly influenced by the thermal treatments for both species. Nevertheless, specific gravity $\left(\rho_{\mathrm{b}}\right)$ did not significantly vary as a function of pre-treatment
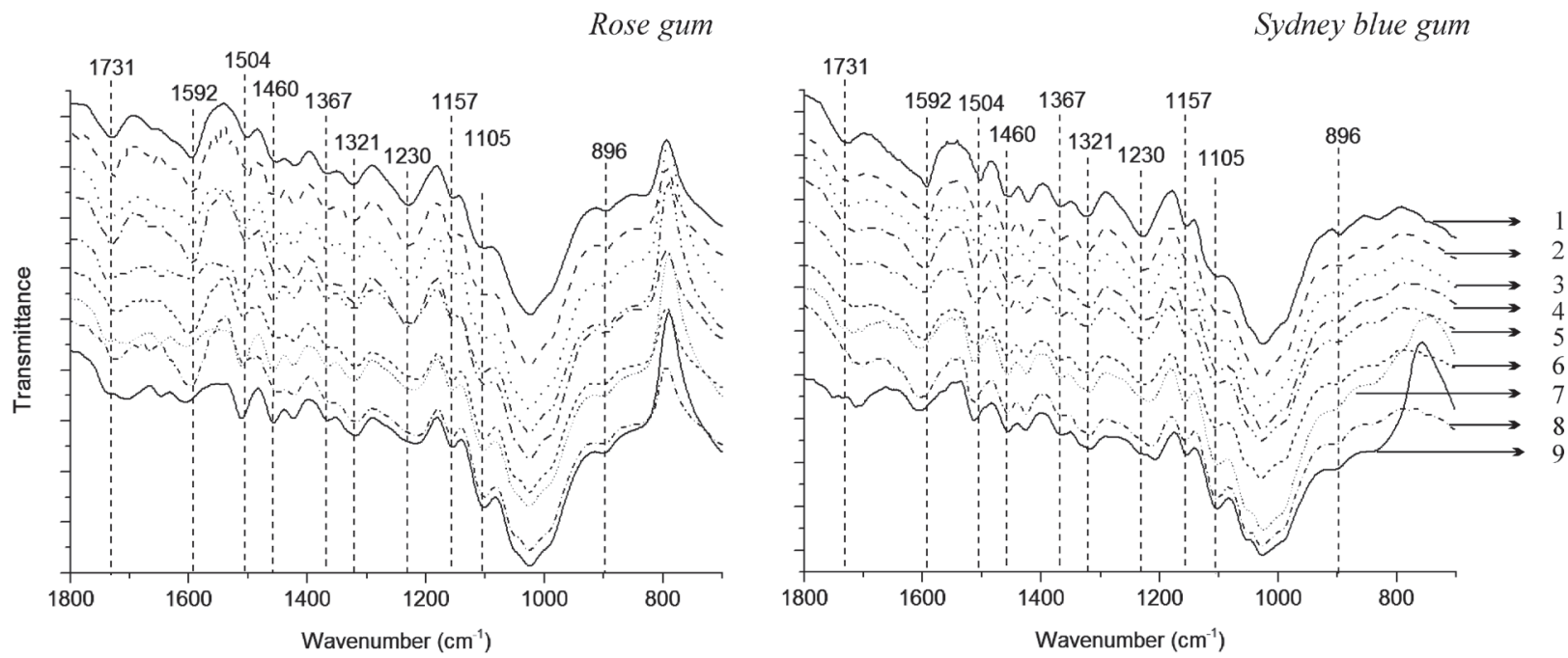

Figure 1 - ATR-IR spectra of untreated and thermally treated wood. 
in the autoclave and temperature of heat treatment in oven factors. Pre-treatment in the autoclave was significant only for mass loss (WL) of both species studied and the equilibrium moisture content (EMC) of Sydney blue gum wood. The contrast Fact. vs Control was significant for all the properties evaluated, except for $\rho_{\mathrm{b}}$, which proves the influence of thermal treatments applied on hygroscopicity of rose gum and Sydney blue gum woods.
Mass loss (WL) of thermally modified woods from two Eucalyptus species showed directly proportional behavior as a function of temperature of exposure (Table III), i.e, mass loss increased with increasing temperature of treatment in oven.

Mean values of WL significantly ranged from 12 to $25 \%$ for all the species, in which rose gum wood showed the lowest (12.63\%), while Sydney blue gum wood presented the highest (24.47\%).

TABLE II

Summary of the analysis of variance of the physical properties of thermally treated rose gum and Sydney blue gum woods.

\begin{tabular}{|c|c|c|c|c|c|c|c|}
\hline \multirow{6}{*}{ 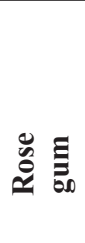 } & & \multicolumn{6}{|c|}{ F-value } \\
\hline & & $\mathbf{W L}$ & $\rho_{\mathrm{b}}$ & EMC & $\Delta \mathbf{V}$ & Radial $\Delta \mathrm{I}$ & Tangential $\Delta \mathrm{l}$ \\
\hline & Pre-treatment (A) & $22.69^{*}$ & $0.75^{\text {ns }}$ & $2.32^{\mathrm{ns}}$ & $0.02^{\mathrm{ns}}$ & $0.29^{\mathrm{ns}}$ & $1.31^{\mathrm{ns}}$ \\
\hline & Temperature (B) & $392.59^{*}$ & $0.94^{\mathrm{ns}}$ & $9.82^{* *}$ & $24.40^{* *}$ & $10.78^{* *}$ & $37.58^{* *}$ \\
\hline & A vs. B & $15.17^{*}$ & $0.42^{\mathrm{ns}}$ & $2.70^{*}$ & $0.67^{\mathrm{ns}}$ & $0.46^{\mathrm{ns}}$ & $3.80^{*}$ \\
\hline & Fact. vs. Control & - & $1.05^{\mathrm{ns}}$ & $449.73^{* *}$ & $107.72^{* *}$ & $55.20^{* *}$ & $126.59^{* *}$ \\
\hline \multirow{4}{*}{ 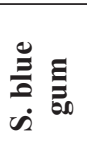 } & Pre-treatment (A) & $23.17^{*}$ & $2.43^{\mathrm{ns}}$ & $25.38^{* *}$ & $1.48^{\mathrm{ns}}$ & $3.19^{\mathrm{ns}}$ & $0.02^{\mathrm{ns}}$ \\
\hline & Temperature (B) & $290.80^{*}$ & $0.41^{\mathrm{ns}}$ & $22.97^{* *}$ & $37.76^{* *}$ & $12.75^{* *}$ & $28.52^{* *}$ \\
\hline & A vs. B & $13.46^{*}$ & $0.08^{\mathrm{ns}}$ & $7.20^{* *}$ & $3.32^{*}$ & $3.43^{*}$ & $7.38^{* *}$ \\
\hline & Fact. vs. Control & - & $2.57^{\mathrm{ns}}$ & $704.26^{* *}$ & $88.66^{* *}$ & $106.30^{* *}$ & $99.74^{* *}$ \\
\hline
\end{tabular}

Fact $=$ Factorial $;$ Control $=$ Control treatment (untreated samples) $;{ }^{\text {ns }}=$ not significant; $* *=$ Significant at $1 \%$ of probability of error; $*=$ Significant at $5 \%$ of probability of error.

TABLE III

Mean values of mass loss (WL), specific gravity $\left(\rho_{\mathrm{b}}\right)$ and equilibrium moisture content (EMC) of rose gum and Sydney blue gum thermally modified woods.

\begin{tabular}{|c|c|c|c|c|c|c|}
\hline \multicolumn{7}{|c|}{ Rose gum } \\
\hline & & Control & $180^{\circ} \mathrm{C}$ & $200^{\circ} \mathrm{C}$ & $220^{\circ} \mathrm{C}$ & $240^{\circ} \mathrm{C}$ \\
\hline \multirow{2}{*}{ WL $(\%)$} & $\mathrm{AC}$ & \multirow{2}{*}{ 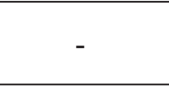 } & $12.63(0.31) \mathrm{aA}$ & $15.05(1.51) \mathrm{aB}$ & $16.91(1.69) \mathrm{aC}$ & $22.53(1.30) \mathrm{aD}$ \\
\hline & $\mathrm{S} / \mathrm{AC}$ & & $13.63(0.25) \mathrm{bA}$ & $14.90(0.49) \mathrm{aB}$ & $20.21(1.23) \mathrm{bC}$ & $22.39(1.20) \mathrm{aD}$ \\
\hline \multirow{2}{*}{$\rho_{\mathrm{b}}\left(\mathrm{g} \cdot \mathrm{cm}^{-3}\right)$} & $\mathrm{AC}$ & \multirow{2}{*}{$0.42(0.04)$} & $0.41(0.06) \mathrm{aA}$ & $0.41(0.05) \mathrm{aA}$ & $0.39(0.05) \mathrm{aA}$ & $0.39(0.07) \mathrm{aA}$ \\
\hline & $\mathrm{S} / \mathrm{AC}$ & & $0.41(0.05) \mathrm{aA}$ & $0.38(0.04) \mathrm{aA}$ & $0.40(0.05) \mathrm{aA}$ & $0.38(0.04) \mathrm{aA}$ \\
\hline \multirow{2}{*}{$\operatorname{EMC~}(\%)$} & $\mathrm{AC}$ & \multirow{2}{*}{$13.67(1.66)$} & $6.89(1.34) \mathrm{aA}$ & $4.42(0.81) \mathrm{aB}$ & $5.32(1.92) \mathrm{aB}$ & $4.34(1.11) \mathrm{bB}$ \\
\hline & $\mathrm{S} / \mathrm{AC}$ & & $6.19(1.40) \mathrm{aA}$ & $4.93(0.88) \mathrm{aA}$ & $5.71(0.44) \mathrm{aA}$ & $5.71(1.59) \mathrm{aA}$ \\
\hline \multicolumn{7}{|c|}{$\begin{array}{l}\text { Sidney blue gum } \\
\end{array}$} \\
\hline & & Control & $180^{\circ} \mathrm{C}$ & $200^{\circ} \mathrm{C}$ & $220^{\circ} \mathrm{C}$ & $240^{\circ} \mathrm{C}$ \\
\hline \multirow{2}{*}{ WL $(\%)$} & $\mathrm{AC}$ & \multirow{2}{*}{ - } & $12.77(0.31) \mathrm{aA}$ & $14.46(1.27) \mathrm{aB}$ & $19.12(2.34) \mathrm{aC}$ & $21.93(1.45) \mathrm{aD}$ \\
\hline & $\mathrm{S} / \mathrm{AC}$ & & $13.50(0.36) \mathrm{bA}$ & $17.20(1.38) \mathrm{bB}$ & $17.92(1.08) \mathrm{aB}$ & $24.47(1.57) \mathrm{bC}$ \\
\hline \multirow{2}{*}{$\rho_{\mathrm{b}}\left(\mathrm{g} \cdot \mathrm{cm}^{-3}\right)$} & $\mathrm{AC}$ & \multirow{2}{*}{$0.46(0.03)$} & $0.50(0.07) \mathrm{aA}$ & $0.52(0.07) \mathrm{aA}$ & $0.50(0.07) \mathrm{aA}$ & $0.50(0.04) \mathrm{aA}$ \\
\hline & $\mathrm{S} / \mathrm{AC}$ & & $0.49(0.07) \mathrm{aA}$ & $0.49(0.08) \mathrm{aA}$ & $0.47(0.07) \mathrm{aA}$ & $0.48(0.04) \mathrm{aA}$ \\
\hline \multirow{2}{*}{ EMC (\%) } & $\mathrm{AC}$ & \multirow{2}{*}{$12.23(1.12)$} & $6.11(0.88) \mathrm{aA}$ & $4.23(1.19) \mathrm{aBC}$ & $4.77(0.66) \mathrm{bB}$ & $3.32(0.78) b C$ \\
\hline & $\mathrm{S} / \mathrm{AC}$ & & $5.91(1.31) \mathrm{aAB}$ & $4.64(1.26) \mathrm{aC}$ & $6.37(0.54) \mathrm{aA}$ & $5.14(0.80) \mathrm{aBC}$ \\
\hline
\end{tabular}

Mean values in the same column followed by the same lowercase letter or in the same line followed by the same uppercase letter for each parameter evaluated are not statistically different at level of 5\% by the Tukey test. Values between parentheses corresponding to the standard deviation. $\mathrm{AC}=$ pre-treatment in autoclave; $\mathrm{S} / \mathrm{AC}=$ absence of pre-treatment in autoclave. 
Mass loss occurs in high levels when wood is thermally modified in closed systems. However, this depends of temperature and atmosphere of treatments. Moreover, high levels of mass loss could be observed in treatments with air, wet conditions and hardwoods. On the other hand, low levels of mass loss occurs in treatments with inert atmospheres, open systems, dry conditions and softwoods (Hill 2006). Obtainment of high mean values of mass loss in this study was possibly due to the initial point of thermal treatments, which was the equilibrium moisture content $(\sim 12 \%)$. Therefore, part of WL is attributed to loss of water in the anatomical structure of wood. According to Surini et al. (2012), mass loss has high correlation to the moisture content of thermally treated wood. Bal and Bektas (2012) stated that the higher the mass loss, the higher the physical and mechanical modifications of the material will be.

According to Table III, $\rho_{\mathrm{b}}$ did not show significant differences, which was also found by Calonego et al. (2012) in a study with rose gum. The mean values were $0.38-0.42 \mathrm{~g} . \mathrm{cm}^{-3}$ (rose gum) and 0.46-0.52 g.cm ${ }^{-3}$ (Sydney blue gum).

Treatment at $180^{\circ} \mathrm{C}$ was sufficient to modify significantly the hygroscopicity of wood from the two species. This result was also found in other studies (Calonego et al. 2012, Esteves et al. 2007, Garcia et al. 2012). Moreover, from treatment at $220^{\circ} \mathrm{C}$, values of EMC (Table III) significantly ranged between treatments with or without use of autoclave for Sydney blue gum wood, while this behavior was observed only in treatment at $240^{\circ} \mathrm{C}$ for rose gum wood.

The changes in EMC could be explained due to the decrease of $\mathrm{OH}$ groups, cleavage of the chains and loss of substances after exposure to high temperatures (Akyildiz and Ates 2008). The reduction of EMC in the present study was inversely proportional to the WL, which was also found by Esteves et al. (2007).

Volumetric swelling $(\Delta \mathrm{V})$ decreased significantly as a function of temperature of treatment in oven
(Table IV) for both species studied, which confirms the modifications in the wood hygroscopicity. Pretreatment in autoclave was only influenced in the treatment at $200^{\circ} \mathrm{C}$ for Sydney blue gum wood. The highest reduction of $\Delta \mathrm{V}$ in both species was observed in more drastic temperatures applied, which was $64 \%$ and $\sim 65 \%$ in rose gum and Sydney blue gum woods, respectively.

Linear swelling $(\Delta \mathrm{l})$ in both radial and tangential direction for both rose gum and Sydney blue gum woods showed significant reduction. Pre-treatment in autoclave was significant only for Sydney blue gum wood, while temperature of exposure in oven was significant in both radial and tangential directions of both species studied. The highest reduction of $\Delta 1$ in radial section was $\sim 60 \%$ and in tangential section was $\sim 70 \%$, both measured in rose gum wood treated at $240^{\circ} \mathrm{C}$.

Bak and Németh (2012) reported that changes in sorption of thermally treated wood are highly influenced by species. However, rose gum and Sydney blue gum showed similar behavior of dimensional stability in the present study, possibly due to homogeneous degradation of amorphous region in hemicelluloses, which was confirmed in the infrared spectroscopy analysis previously explained in this study. According to Ding et al. (2011), dimensional stability is determined mainly due to number of $\mathrm{OH}$ free groups on the amorphous polysaccharides present in the wood structure. Other factors can influence the level of swelling on wood such as permeability. Taghiary et al. (2011) observed that permeability of beech wood drastically decreased after exposure to hydrothermal and hygrothermal conditions due to the deposition of extractives on vessel perforations and blocking of fluid transfer through the porous of wood by cell walls.

\section{WETTABILITY}

Fig. 2 shows the kinetic of wetting for untreated and thermal treated samples of rose gum and Sydney blue gum woods. The thermal treatments significantly 
TABLE IV

Mean values of volumetric swelling $(\Delta \mathrm{V})$ and linear swelling $(\Delta \mathrm{I})$ in both radial and tangential direction of rose gum and Sydney blue gum thermally modified woods.

\begin{tabular}{|c|c|c|c|c|c|c|}
\hline \multicolumn{7}{|c|}{ Rose gum } \\
\hline & & Control & $180^{\circ} \mathrm{C}$ & $200^{\circ} \mathrm{C}$ & $220^{\circ} \mathrm{C}$ & $240^{\circ} \mathrm{C}$ \\
\hline \multirow{2}{*}{$\Delta \mathrm{V}(\%)$} & $\mathrm{AC}$ & 17.46 & $13.25(1.49) \mathrm{aA}$ & $9.87(2.37) \mathrm{aB}$ & $8.63(2.00) \mathrm{aBC}$ & $6.28(1.17) \mathrm{aC}$ \\
\hline & $\mathrm{S} / \mathrm{AC}$ & $(2.77)$ & $12.43(3.20) \mathrm{aA}$ & $9.78(2.37) \mathrm{aAB}$ & $8.62(2.66) \mathrm{aB}$ & $7.47(1.65) \mathrm{aB}$ \\
\hline \multirow{2}{*}{ Radial $\Delta \mathrm{l}(\%)$} & $\mathrm{AC}$ & 6.35 & $4.76(1.13) \mathrm{aA}$ & $3.85(1.13) \mathrm{aA}$ & $3.80(1.09) \mathrm{aA}$ & $2.53(0.86) \mathrm{aB}$ \\
\hline & $\mathrm{S} / \mathrm{AC}$ & $(1.20)$ & $4.15(1.16) \mathrm{aA}$ & $3.85(1.25) \mathrm{aAB}$ & $3.79(1.06) \mathrm{aAB}$ & $2.63(0.65) \mathrm{aB}$ \\
\hline \multirow{2}{*}{ Tangential $\Delta \mathrm{l}(\%)$} & $\mathrm{AC}$ & 10.64 & $8.59(1.57) \mathrm{aA}$ & $6.30(1.43) \mathrm{aB}$ & $4.52(1.87) \mathrm{aC}$ & $4.22(1.10) \mathrm{aC}$ \\
\hline & $\mathrm{S} / \mathrm{AC}$ & $(1.76)$ & $7.03(1.41) \mathrm{bA}$ & $6.65(2.00) \mathrm{aAB}$ & $5.39(1.68) \mathrm{aB}$ & $3.23(1.27) \mathrm{aC}$ \\
\hline \multicolumn{7}{|c|}{ Sydney blue gum } \\
\hline & & Control & $180^{\circ} \mathrm{C}$ & $200^{\circ} \mathrm{C}$ & $220^{\circ} \mathrm{C}$ & $240^{\circ} \mathrm{C}$ \\
\hline \multirow{2}{*}{$\Delta \mathrm{V}(\%)$} & $\mathrm{AC}$ & 19.19 & $16.29(3.88) \mathrm{aA}$ & $12.82(3.23) \mathrm{aB}$ & $8.03(1.57) \mathrm{aC}$ & $6.66(1.11) \mathrm{aC}$ \\
\hline & $\mathrm{S} / \mathrm{AC}$ & $(2.66)$ & $14.64(4.66) \mathrm{aA}$ & 9.57 (2.78) bBC & $9.96(3.65) \mathrm{aB}$ & $6.66(1.14) \mathrm{aC}$ \\
\hline \multirow{2}{*}{ Radial $\Delta 1(\%)$} & $\mathrm{AC}$ & 7.96 & $5.57(1.28) \mathrm{aA}$ & $4.95(0.94) \mathrm{aA}$ & $3.48(0.91) \mathrm{aB}$ & $2.79(0.58) \mathrm{aB}$ \\
\hline & $\mathrm{S} / \mathrm{AC}$ & $(1.74)$ & $4.30(1.44) \mathrm{bA}$ & $3.73(0.86) \mathrm{bAB}$ & $4.19(1.47) \mathrm{aA}$ & $2.73(0.54) \mathrm{aB}$ \\
\hline \multirow{2}{*}{ Tangential $\Delta \mathrm{l}(\%)$} & $\mathrm{AC}$ & 10.92 & $8.25(1.33) \mathrm{aA}$ & $7.37(2.15) \mathrm{aA}$ & $3.52(1.43) \mathrm{bB}$ & $4.95(1.00) \mathrm{aB}$ \\
\hline & $\mathrm{S} / \mathrm{AC}$ & $(1.30)$ & $8.43(1.33) \mathrm{aA}$ & $5.51(1.90) \mathrm{bB}$ & $5.89(2.20) \mathrm{aB}$ & $4.42(1.27) \mathrm{aB}$ \\
\hline
\end{tabular}

Mean values in the same column followed by the same lowercase letter or in the same line followed by the same uppercase letter for each parameter evaluated are not statistically different at level of 5\% by the Tukey test. Values between parentheses corresponding to the standard deviation. $\mathrm{AC}=$ pre-treatment in autoclave; $\mathrm{S} / \mathrm{AC}=$ absence of pre-treatment in autoclave.

influenced the apparent contact angle of treated samples when compared to the untreated samples (treatment 1) in both radial and tangential sections. The hydrophobicity of thermally treated wood samples increased without significant differences between radial and tangential sections as described by Kocaefe et al. (2008).

The untreated samples showed a significant and constant decrease of the apparent contact angle as a function of the time, while the thermally treated wood samples presented low decrease rates, mainly in the treatments 2, 3, 4, 5, 6 and 7. An apparent contact angle lower than $90^{\circ}$ in porous materials (wood for example) implies in a spontaneous penetration of the liquid (Wålinder and Gardnerb 1999), which was observed for the treatment 1 (control) in this study. According to Homan et al. (2000), the limited interaction between thermally treated wood and water is related to the reduction of the $\mathrm{OH}$ groups in the structure of hemicelluloses.

The highest increase of the apparent contact angle was observed in treatments 2, 3, 4 and 5. Treatments 8 and 9 (more aggressive) were higher than treatment 1 (control) but were lower than the treatments aforementioned (2, 3, 4 and 5). Therefore, it is possible to affirm that high temperatures applied in the thermal treatments are not always the best condition to obtain great changes in the material surface. Oliveira et al. (2010) described the same wettability behavior found in this study. Pétrissans et al. (2005) suggested that wettability decreases due to increase of cellulose crystallinity, whereas Hakkou et al. (2005) reported that changes in the conformational arrangement of wood is related to the lignin plasticization or the residual water.

Quality of wetting is influenced by many macroscopic characteristics, such as porosity, surface roughness, moisture content and fibers orientation (Kocaefe et al. 2008). Therefore, the most severe treatments applied in this study generated small cracks in the samples surface, which could have had an influence in the wood characteristics such as roughness and porosity and, consequently, in wettability.

The wettability of thermally treated wood is widely related to the material surface inactivation, which is associated to the reduction of attractive 

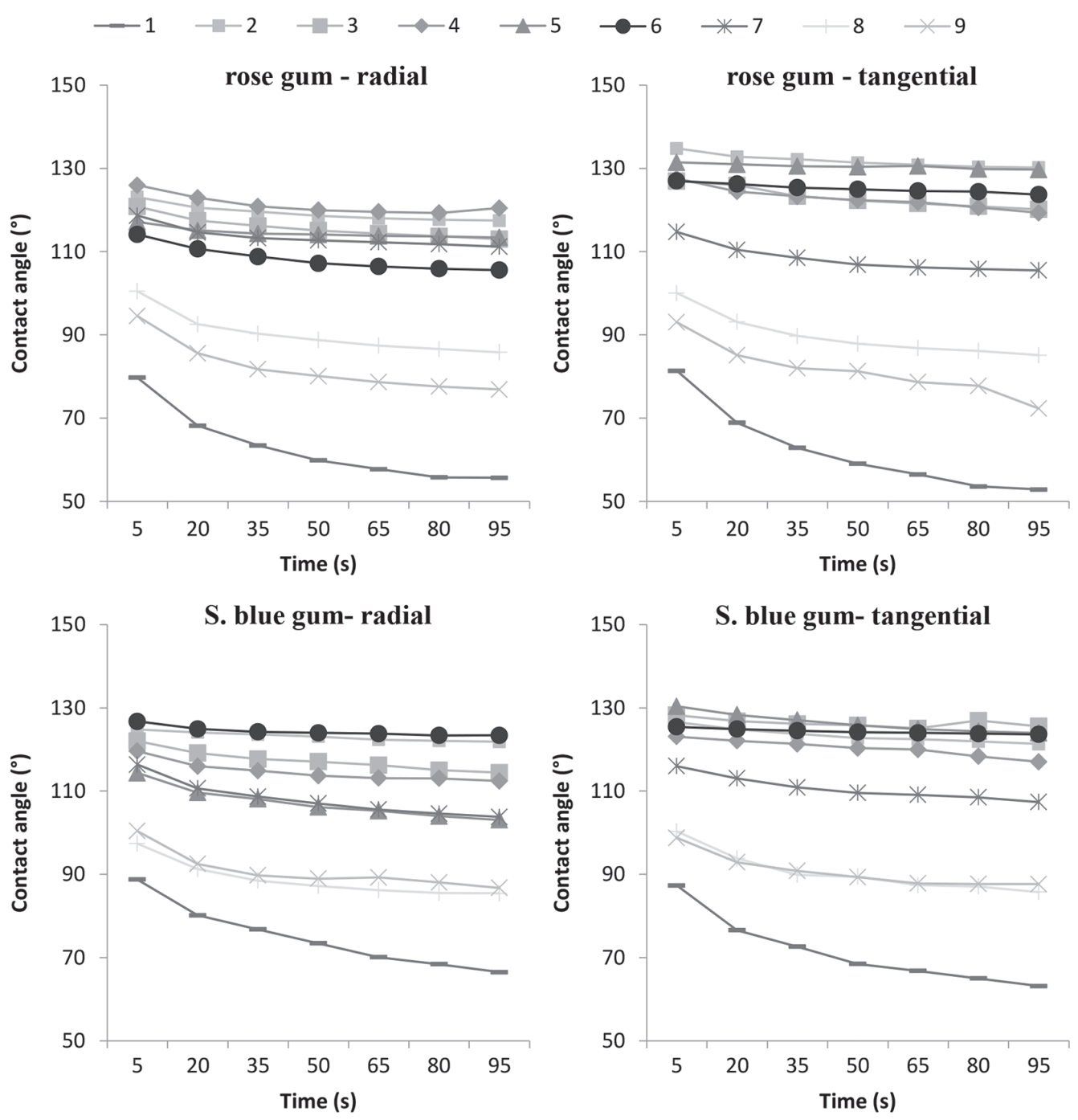

Figure 2 - Kinetic of wetting for untreated and thermally treated wood samples.

forces. According to Christiansen (1991), mechanisms such as molecular surface reorientation, extractives migration for the surface, micropore closure, elimination of surface hydroxyl bonding sites and surface oxidation directly influence the reduction of attractive forces.

\section{MECHANICAL PROPERTIES}

Statistical analysis of mechanical properties (Table V) showed that interaction between pre-treatment in the autoclave and temperature of heat treatment in oven factors was significant only for modulus of rupture (MOR) of rose gum. The contrast Fact. vs Control showed that both MOR of rose gum and Sydney blue gum woods significantly changed after thermal treatments, which implies that mechanical properties of thermally modified wood samples were distinct when compared to the untreated wood samples.

Modulus of elasticity (MOE) of thermally modified woods (Table VI) did not show a tendency as a function of thermal treatments and did not present significant difference in comparison to control treatment, which as previously observed in Table V. The absence of significant range in stiffness is related to the characteristics of the wood developed during the thermal treatment. Bhuiyan et al. (2000) reported 
TABLE V

Summary of the analysis of variance of the mechanical properties of thermally treated rose gum and Sydney blue gum woods.

\begin{tabular}{|c|c|c|c|}
\hline \multirow{6}{*}{$\begin{array}{l}\Xi \\
\Xi \\
\tilde{\sigma}_{0} \\
0 \\
\tilde{w} \\
\tilde{0}\end{array}$} & & \multicolumn{2}{|c|}{ F-value } \\
\hline & & MOE & MOR \\
\hline & Pre-treatment (A) & $1.24^{\mathrm{ns}}$ & $1.29^{\mathrm{ns}}$ \\
\hline & Temperature (B) & $2.07^{\mathrm{ns}}$ & $27.88^{* *}$ \\
\hline & A vs. B & $2.00^{\mathrm{ns}}$ & $6.71^{* *}$ \\
\hline & Fact. vs. Control & $3.03^{\mathrm{ns}}$ & $134.83^{* *}$ \\
\hline \multirow{4}{*}{ 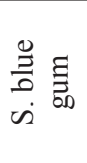 } & Pre-treatment (A) & $1.69^{\mathrm{ns}}$ & $0.06^{\mathrm{ns}}$ \\
\hline & Temperature (B) & $1.53^{\mathrm{ns}}$ & $14.38^{* *}$ \\
\hline & A vs. B & $0.81^{\mathrm{ns}}$ & $0.19^{\mathrm{ns}}$ \\
\hline & Fact. vs. Control & $1.71^{\mathrm{ns}}$ & $51.48^{* *}$ \\
\hline
\end{tabular}

Fact $=$ Factorial; Control $=$ Control treatment (untreated samples); ${ }^{\text {ns }}=$ not significant; $* *=$ Significant at $1 \%$ of probability of error; $*=$ Significant at $5 \%$ of probability of error.

that no changes in stiffness of thermally treated wood are related to the increase of crystallization of cellulose and crystallites thickness of material.

The mechanical strength at static bending, represented by MOR, decreased significantly with increasing temperature of treatment (Table VI). This was expected due to the negative action of thermal treatment on the wood strength. According to Curling et al. (2002), changes in MOR of thermally treated wood are related to the degradation of hemicelluloses, represented in this study through mass loss and confirmed in the infrared spectroscopy analysis due to the decrease of peak intensity related to this chemical component of wood.

Rose gum wood showed significant decrease in MOR after treatment 2, which was not observed for Sydney blue gum wood, which had higher specific gravity than the first. Considering each treatment as a function of use or not of pre-treatment in autoclave, MOR of rose gum wood was significantly different only in the treatment at $220^{\circ} \mathrm{C}$, while Sydney blue gum wood did not show significant differences.

Rose gum wood showed the highest brittleness after thermal treatments. Loss of mechanical strength in this specie was between $\sim 22$ and $\sim 58 \%$, similar to what was found for the same specie by Calonego et al. (2012). According to Vernois (2000), the mechanical properties of thermally modified wood is dependent upon the conditions of process, such as temperature, type of treatment and characteristics of material (specie for example). The author stated that wood tends to become more brittle after thermal treatment, in which a treatment at $230^{\circ} \mathrm{C}$ could determine a loss of strength between 30 and $40 \%$.

Moreover, Mburu et al. (2008) reported that mass loss is one of the most common factors that influences the mechanical strength of thermally modified wood. The authors observed a directly proportional behavior between these properties. As previously stated, the highest mass loss was in the last treatment that rendered the highest loss of mechanical strength.

\section{CONCLUSIONS}

In general, thermal treatments showed a significant potential to increase some physical and surface properties of rose gum and Sydney blue gum woods. Pre-treatment in autoclave significantly changed some properties analyzed, however the highest modifications were observed in thermal treatments performed in oven at $180-240^{\circ} \mathrm{C}$.

Changes on dimensional stability confirmed decreases of the wood hygroscopicity of both species.

Wettability of thermally treated samples decreased when compared to untreated samples and the chemical structure changed, mainly due to the degradation of hemicelluloses.

Significant loss of mechanical strength was found as a function of temperature of treatment in oven.

Increase of dimensional stability without significant decrease of mechanical strength was not observed on the same thermal treatment applied.

\section{ACKNOWLEDGMENTS}

The authors wish to thank Conselho Nacional de Desenvolvimento Científico e Tecnológico (CNPq), Coordenação de Aperfeiçoamento de Pessoal de Nível Superior (CAPES) and University of Basque Country (Spain) for supporting this work. 
TABLE VI

Mean values of modulus of elasticity (MOE) and modulus of rupture (MOR) of rose gum and Sydney blue gum thermally modified wood.

\begin{tabular}{|c|c|c|c|c|c|c|}
\hline \multicolumn{7}{|c|}{ Rose gum } \\
\hline & & Control & $180^{\circ} \mathrm{C}$ & $200^{\circ} \mathrm{C}$ & $220^{\circ} \mathrm{C}$ & $240^{\circ} \mathrm{C}$ \\
\hline \multirow{2}{*}{$\begin{array}{l}\text { MOE } \\
(\mathrm{MPa})\end{array}$} & $\mathrm{AC}$ & \multirow{2}{*}{$12097(980)$} & $12091(1468) \mathrm{aAB}$ & $12271(1524) \mathrm{aA}$ & 10919 (1549) aAB & $10623(1511) \mathrm{aB}$ \\
\hline & $\mathrm{S} / \mathrm{AC}$ & & $11053(1656) \mathrm{aA}$ & 11168 (1949) aA & $11463(1838) \mathrm{aA}$ & $10871(1172)$ aA \\
\hline \multirow{2}{*}{$\begin{array}{l}\text { MOR } \\
(\mathrm{MPa})\end{array}$} & $\mathrm{AC}$ & \multirow{2}{*}{$89(10)$} & $69(8) \mathrm{aA}$ & $61(8) \mathrm{aA}$ & $37(7) \mathrm{bB}$ & $41(10) \mathrm{aB}$ \\
\hline & $\mathrm{S} / \mathrm{AC}$ & & $61(13) \mathrm{aA}$ & $59(13) \mathrm{aA}$ & $54(9) \mathrm{aAB}$ & $45(9) \mathrm{aB}$ \\
\hline \multicolumn{7}{|c|}{ Sidney blue gum } \\
\hline & & Control & $180^{\circ} \mathrm{C}$ & $200^{\circ} \mathrm{C}$ & $220^{\circ} \mathrm{C}$ & $240^{\circ} \mathrm{C}$ \\
\hline \multirow{2}{*}{$\begin{array}{l}\mathrm{MOE} \\
(\mathrm{MPa})\end{array}$} & $\mathrm{AC}$ & \multirow{2}{*}{12869 (1229) } & 13805 (1357) aA & $14395(2460) \mathrm{aA}$ & $13876(1454) \mathrm{aA}$ & 13568 (1726) aA \\
\hline & $\mathrm{S} / \mathrm{AC}$ & & 13248 (1306) aA & $13474(1782) \mathrm{aA}$ & 14385 (2041) aA & 12463 (2254) aA \\
\hline \multirow{2}{*}{$\begin{array}{l}\text { MOR } \\
(\mathrm{MPa})\end{array}$} & $\mathrm{AC}$ & \multirow{2}{*}{$90(12)$} & $75(16) \mathrm{aA}$ & $59(9) \mathrm{aB}$ & $56(16) \mathrm{aB}$ & $47(11) \mathrm{aB}$ \\
\hline & $\mathrm{S} / \mathrm{AC}$ & & $73(13) \mathrm{aA}$ & $56(13) \mathrm{aB}$ & $57(17) \mathrm{aB}$ & $48(14) \mathrm{aB}$ \\
\hline
\end{tabular}

Mean values in the same column followed by the same lowercase letter or in the same line followed by the same uppercase letter for each parameter evaluated are not statistically different at level of 5\% by the Tukey test. Values between parentheses corresponding to the standard deviation. $\mathrm{AC}=$ pre-treatment in autoclave; $\mathrm{S} / \mathrm{AC}=$ absence of pre-treatment in autoclave.

\section{RESUMO}

Avaliou-se o efeito da termorretificação nas propriedades físicas e mecânicas da madeira de Eucalyptus grandis e Eucalyptus saligna. Amostras de madeira foram modificadas termicamente por meio de uma combinação: pré-tratamento em autoclave $\left(127^{\circ} \mathrm{C}-1 \mathrm{~h}\right)$ e tratamento em estufa $\left(180-240^{\circ} \mathrm{C}-4 \mathrm{~h}\right)$; bem como tratamento apenas em estufa a $180-240^{\circ} \mathrm{C}$ durante $4 \mathrm{~h}$. As modificações químicas foram avaliadas por espectroscopia no infravermelho. A avaliação das propriedades físicas foi realizada por meio de ensaios de perda de massa, massa específica básica, teor de umidade de equilíbrio e estabilidade dimensional. Modificações na superfície do material foram analisadas pela técnica de ângulo de contato e o comportamento mecânico foi avaliado com testes de flexão estática. O uso de pré-tratamento em autoclave afetou as propriedades analisadas, no entanto a exposição em estufa denotou as maiores modificações na madeira de ambas a espécies. As modificações químicas foram relacionadas com a degradação das hemiceluloses. Além disso, observou-se redução significativa da higroscopicidade e da resistência mecânica da madeira termorretificada, enquanto que a massa específica básica não possuiu modificações significativas para a madeira das duas espécies estudadas.
Os melhores resultados de redução da molhabilidade foram encontrados para as temperaturas mais baixas, enquanto que a estabilidade dimensional elevou-se em função da temperatura de tratamento em estufa. A maior perda de resistência mecânica foi observada no tratamento a $240^{\circ} \mathrm{C}$ para ambas as espécies.

Palavras-chave: higroscopicidade, modificações químicas, molhabilidade, termorretificação, resistência mecânica.

\section{REFERENCES}

AKYILDIZ MH AND ATES S. 2008. Effect of heat treatment on equilibrium moisture content (EMC) of some wood species in Turkey. Research Journal of Agriculture and Biological Sciences 4: 660-665.

Australian/NEW ZEALAND STANDARD (AS/NZS) 2878. 2000. Timber - Classification into strength groups.

ASTM D143-94. 2000. Standards methods of testing small clear specimens of timber. In: Annual Book of standards. West Conshohocken, PA.

BAK M AND NÉMETH R. 2012. Changes in swelling properties and moisture uptake rate of oil-heat-treated poplar (Populus x euramericana CV. Pannónia) wood. Bioresources 7: 5128-5137.

BAL BC AND BEKTAS I. 2012. The effects of heat treatment on the physical properties of juvenile wood and mature wood of Eucalyptus grandis. Bioresources 7: 5117-5127.

BHUIYAN MTR, HiRAi N AND SobuE N. 2000. Changes of crystallinity in wood cellulose by heat treatment under dried and moist conditions. J Wood Sci 46: 431-436. 
BORREGA M AND KÄRENLAMPI P. 2008. Mechanical behavior of heat-treated spruce (Picea abies) wood at constant moisture content and ambient humidity. Eur J Wood Wood Prod 66: 63-69.

Cademartori PHG, Scheneid E, Gatto DA, Beltrame R AND STANGERLIN DM. 2012. Modification of Static Bending Strength Properties of Eucalyptus grandis HeatTreated Wood. Materials Research 15: 922-927.

Cademartori PHG, Santos PSB, Serrano L, Labidi J AND GATTO DA. 2013. Effect of thermal treatment on physicochemical properties of Gympie messmate wood. Ind Crop Prod 45: 360-366.

Calonego F, Severo E and Ballarin A. 2012. Physical and mechanical properties of thermally modified wood from E. grandis. Eur J Wood Wood Prod 70: 453-460.

CHRISTIANSEN AW. 1991. How overdrying wood reduces its bonding to phenol-formaldehyde adhesives: a critical review of the literature. Part II, Chemical reactions. Wood Fiber Sci 23: 69-84.

Colom X, CARrillo F, Nogués F AND GARriga P. 2003. Structural analysis of photodegraded wood by means of FTIR spectroscopy. Polym Degrad Stabil 80: 543-549.

Curling SF, Clausen CA AND Winandy JE. 2002. Experimental method to quantify progressive stages of decay of wood by basidiomycete fungi. Int Biodeter Biodegr 49: 13-19.

DING T, GU L AND LIU X. 2011. Influence of steam pressure on chemical changes of heat-treated mongolian pine wood. Bioresources 6: 1880-1889.

Esteves B, Marques A, Domingos I And Pereira H. 2007. Influence of steam heating on the properties of pine (Pinus pinaster) and eucalypt (Eucalyptus globulus) wood. Wood Sci Technol 41: 193-207.

Fengel D And Wegener G. 2003. Wood Chemistry, Ultrastructure, Reactions. Berlin/New York: Walter de Gruyter, $613 \mathrm{p}$.

Garcia R, Carvalho A, Figueiredo Latorraca J, Matos J, Santos W and Medeiros Silva R. 2012. Nondestructive evaluation of heat-treated Eucalyptus grandis Hill ex Maiden wood using stress wave method. Wood Sci Technol 46: 41-52.

HAKKou M, PÉTrissans M, Zoulalian A AND GÉRARdin P. 2005. Investigation of wood wettability changes during heat treatment on the basis of chemical analysis. Polym Degrad Stabil 89: 1-5.

HILL CAS. 2006. Wood Modification: Chemical, Thermal and Other Processes. 1st ed. Chichester: John Wiley \& Sons, 260

Homan W, TJeerdsma B, Beckers E AND Jorissen A. 2000. Structural and Other Properties of Modified Wood. Proceedings World Conference on Timber Engineering. p.8.

Kocaefe D, Poncsak S, Doré G AND Younsi R. 2008. Effect of heat treatment on the wettability of white ash and soft maple by water. Eur J Wood Wood Prod 66: 355-361.
KORKUT DS AND GULLER B. 2008. The effects of heat treatment on physical properties and surface roughness of red-bud maple (Acer trautvetteri Medw.) wood. Bioresource Technol 99: 2846-2851.

Korkut DS, KoRKuT S, BEKAR I, BUDAKÇI M, DiLIK T AND ÇAKICIER N. 2008. The effects of heat treatment on the physical properties and surface roughness of Turkish Hazel (Corylus colurna L.) Wood. Int J Mol Sci 9: 1772-1783.

Mburu F, Dumarçay S, Bocquet JF, Petrissans M AND GÉRARDIN P. 2008. Effect of chemical modifications caused by heat treatment on mechanical properties of Grevillea robusta wood. Polym Degrad Stabil 93: 401-405.

MiLiTz H. 2002. Heat treatment technologies in Europe: Scientific background and technological state-of-art. Proceedings Enhancing the Durability of Lumber and Engineered Wood Products, $19 \mathrm{p}$.

MitCHELL PH. 1988. Irreversible property changes of small loblolly pine specimens heated in air, nitrogen, or oxygen. Wood and Fiber Science 20: 320-355.

Oliveira RMD, Brisolari A, SAles A AND GonçAlves D. 2010. Wettability, shrinkage and color Changes of Araucaria angustifolia after heating treatment. Materials Research 13: 351-354.

PANDEY KK. 1999. A study of chemical structure of soft and hardwood and wood polymers by FTIR spectroscopy. J Appl Polym Sci 71: 1969-1975.

Pétrissans M, GÉrardin P, BaKali IE ANd Serraj M. 2005. Wettability of heat-treated wood. Holzforschung 57: 301-307.

Poncsák S, Kocaefe D, Bouazara M AND PichetTe A. 2006. Effect of high temperature treatment on the mechanical properties of birch (Betula papyrifera). Wood Sci Technol 40: 647-663.

Surini T, Charrier F, MALvestio J, Charrier B, Moubarik A, CAstéra P AND Grelier S. 2012. Physical properties and termite durability of maritime pine (Pinus pinaster Ait.) heat-treated under vacuum pressure. Wood Sci Technol 46: 487-501.

SYRJANEN T. 2001. Production and classification of heat treated wood in Finland. Review on heat treatments of wood. Proceedings of the Special Seminar Held in Antibes, p. 7-16.

TAGHIYARI HR, TALAEI A AND KARIMI A. 2011. A correlation between the gas and liquid permeabilities of beech wood heat-treated in hot water and steam mediums. Maderas, Cienc Tecnol 13: 329-336.

VernoIs M. 2000. Heat treatment in France. Proceedings Production and Development of Heat Treated Wood in Europe.

WÅLINDER MEP AND GARDNERB DJ. 1999. Factors influencing contact angle measurements on wood particles by column wicking. J Adhes Sci Technol 13: 1363-1374. 
